Changing Societies \& Personalities, 2017

Vol. 1, No. 4

http://dx.doi.org/10.15826/csp.2017.1.4.022

\title{
ARTICLE
}

\section{Human Rights Advocacy of Baptist Initiators}

\author{
Tatyana Nikolskaya
}

Saint Petersburg Christian University, Russia

\begin{abstract}
Among Soviet believers who spoke in defence of their rights, the Baptist Initiators stand out. They collected information about persecutions, provided prayer, moral, material support, human rights assistance to convicted co-religionists and their families and opposed state interference in the affairs of the church. In defending the rights of believers, they also appealed to international public opinion. Women were extensively involved in this activity. In 1964, the Council of Relatives of Prisoners was created, which issued a special "Bulletin". Although activists within the movement were regularly subjected to repression, their activities objectively influenced the adjustment of Soviet religious policy towards Evangelical Christian Baptists.
\end{abstract}

\section{KEYWORDS}

Evangelical Christian-Baptists, Initiators, human rights activities, Council of Churches, Council of Relatives of Prisoners

\section{Introduction}

In contemporary Russia, Russian Protestants (Evangelical Christians, Baptists, Pentecostals and Seventh Day Adventists) are generally contented with their situation. During the time that has passed since 1991, an entire generation has grown up, who may not any more face persecution on account of their faith, but who are at the same time vaguely cognisant of Soviet realities. It can be said that in their entire 150-year history, Russian Protestants have never enjoyed so much freedom or so many opportunities for the development of their churches and various associated activities - as well as for their personal prosperity.

In order to resolve emerging legal issues, Protestant organisations and large communities engage professional lawyers to deal with the protection of their clients' interests. The present Russian authorities do not impede the 
existence of unregistered religious groups or entire denominations-i.e. those who do not conform to state registration: among them, the International Union of Churches of Evangelical Christian Baptists (IUCECB) and the United Church of Evangelical Christians (UCEC).

However, some recently developing circumstances have begun to cause concerns within the Protestant community. Following the adoption of the so-called "Yarovoya Law", repeated cases have been established when Protestants of different denominations are liable for violations of the missionary activity rules.

On April 20, 2017, the Supreme Court of the Russian Federation took the decision to liquidate the Administrative Centre of Jehovah's Witnesses in Russia and all its local religious organisations, and to confiscate their property. The main accusation was "extremist activity", although, in reality, the adherents of this organisation profess pacifist principles. Thus, 175,000 Russian citizens were deprived of the right to freely profess their faith, as well as to receive legal protection against increased attacks (Persecution of Jehovah's Witnesses in Russia, 2017). The Christian community showed mixed reactions to this event: some expressed satisfaction that the authorities had "banned heretics"; others interpreted this case as a dangerous precedent that could be used against other denominations.

As for the media space, at least at the state level, the coverage of the "sectarian" theme has so far been rather cautious. For example, in 2015, news reports about the mass murders in the city of Gyumri (Armenia) and Nizhny Novgorod did not place special emphasis on the confession of the murderers, despite the fact that in the first case the guilty was the son of a Pentecostal pastor, and, in the second, a parishioner of the Seventh-day Adventist church. At the same time, on Russian television, tendentious programmes periodically appear, in which so-called "sectarians" are accused of fraud, political unreliability or even subversion (for example, the television programme "The Conspiracy Theory. Espionage under the Guise of Religion", shown on October 16, 2017 on the Zvezda TV channel).

In this context, attempting to address the historical experience of Russian Protestants becomes a highly relevant endeavour: what were the consequences of protection of their own and other believers' rights; how did they perceive persecution and discrimination in the past by the state and society; how did this take place and with what results?

When studying the history of the dissident movement in the USSR, the majority of attention has tended to be focused on political and national communities. The human rights movement associated with Russian Protestantism has been studied to a significantly lesser extent, despite it arguably being more significant in terms of the number of people involved and the degree of its influence. If the political dissidents were grouped mainly in closed circles of intellectuals in a number of large cities, tens, if not hundreds of thousands of people, both church members and their relatives, were involved in the human rights struggle of Russian Protestants (Baptist Initiators, Adventist reformers, Pentecostals), representing different social strata, nationalities, professions, level of education and places of residence. It can therefore be claimed 
that Protestants formed the only mass human rights movement in the USSR among the Russian people.

Among Soviet believers who spoke in defence of their rights, Baptist Initiators are especially prominent. In the 30 years from 1961 to 1991 , they actively participated in human rights activities: collecting information about persecutions, providing prayer, moral, material and legal assistance to convicted co-religionists and their families, opposing state interference in church affairs and campaigning for the rights of believers - including the right of the parents to give their children religious education - to be respected. They sent delegations and letters with petitions to government bodies, party and state institutions and the mass media of the USSR, as well as to international actors.

Despite the existence of laws on freedom of conscience and the assertions of Soviet propaganda that persecutions for religious faith were absent in the USSR, the real situation was rather different. a number of prohibitions restricted church activities. Many religious communities lacked state registration, for which they were fined and persecuted, including the arrests of ministers and activists. Officials of the Council for Religious Affairs, which was responsible for regulating religious organisations, interfered in the internal life of churches. Believers, especially so-called "sectarians" (i.e. non-Russian Orthodox), often experienced discrimination in educational and professional spheres, as well as ostracism and contempt in the wider society. In the late 1950's, a large-scale anti-religious campaign was launched across the country.

The beginning of the Initiators movement dates back to August 1961. a group of Evangelical Christian Baptist ministers, headed by Gennady Kryuchkov and Alexei Prokofiev, issued an encyclical letter, which announced the creation of the Initiative Group for the preparation and holding of the All-Union Extraordinary Congress of Evangelical Christians-Baptists (ECB). This "Initiative Group" has given its name to the "Initiators' movement" or "the Initiators" - both terms are widespread in the literature and historiography.

Kryuchkov and Prokofiev were concerned not so much by the intensification of persecution and the outbreak of the anti-religious campaign, as by (as they saw it) the excessive accommodation of the leadership of the All-Union Council of ECB (AUCECB) towards state structures. The trigger for the establishing of the Initiative Group was the AUCECB's issue of some instructive documents, which significantly limited intra-church activities.

In 1962, supporters of the Initiative Group finally withdrew from their subordination to the AUCECB. As a result of this schism, the alternative church structure of Evangelical Christian Baptists headed by the Council of Churches (CC) of the ECB was established in the USSR (Nikolskaya, 2009, pp. 202-203). While in terms of doctrines the Initiators were almost identical to their loyalist colleagues, nevertheless, they placed a special emphasis on the independence of the church and the state. Without trying to change anything fundamentally in the Soviet system, the Initiators consistently, for many years, sought to influence the Soviet government and local authorities to accurate execution of their own laws on freedom of conscience, as well as those international human rights provisions recognised by the USSR. 
The activities of the Initiators were diverse: the creation of an independent church structure, the publication of Christian literature and periodicals, the organisation of children's Sunday schools and youth summer camps, etc. Due to the space limit, in this article we will consider only one area of their activity: the struggle for the rights of believers.

\section{Causes of the phenomenon}

Traditionally, Evangelical Christians and Baptists were not interested themselves in political and civil activity; to this day, many consider politics to be a matter unworthy of a Christian. Even such an authoritative Evangelical leader as Ivan Prokhanov, the Chairman of the Union of Evangelical Christians, in the beginning of XX century, did not find the support of his co-religionists in his attempt in 1906 to create a Christian political party called "Union of Freedom, Truth and Peace" (History of Evangelical Christian Baptists of Russia, 2007, p. 71). The majority of believers remained apolitical and simply loyal to the state. They considered the main task for their churches to be the spread of the good news about Christ to all people, regardless of their political views. In addition, one of the guiding principles of Baptism is the separation of church and state, which believers tended to interpret as political neutrality. Last, but not least, Russian Baptists had before them the example of the Orthodox Church, which following the 1917 revolution, paid a brutal price for their political support of the autocracy.

What then happened in the 1960s to prompt a significant proportion of ECB to start to participate in activities, which used to be non-typical for them? Firstly, they were influenced by the historical situation of the late 1950s and early 1960s: the Khrushchev's "thaw"; the weakening of totalitarian power; the de-Stalinisation and partial democratisation of Soviet society; the mass liberation of political prisoners; the emergence of glasnost and relative freedom of speech together with a wearing of the "Iron Curtain", and improving relations with the countries of the capitalist world.

Secondly, believers, especially of the younger generation, possessed increased social self-awareness and were more inclined towards civic engagement. Consequently, many Baptists saw human rights activity in terms of an opportunity to change their plight. Unwittingly, this process was partially facilitated by the appeals of Soviet government propaganda for citizens to liberate themselves from the "legacy of Stalinism" and return to "Leninist norms". Many Baptists understood this in terms of the non-intervention of the state in the internal affairs of religious societies. The alleged heyday of the 1920s, glorified in the era of the "thaw", was associated with the relative religious freedom that the Baptists had enjoyed under Lenin.

It is therefore no accident that Initiators interpreted the oppression of believers as a "shameful legacy of the period of the personality cult (i.e. Stalinism-T. N.), which holds sway over the minds of many responsible workers and entire institutions" and expressed the hope that "as democracy and freedom deepen, those restrictions, which are in the regulations and laws now, should also be removed" (Memorandum of the Organising Committee, 1962, pp. 4-5). References to the struggle against the personality cult were also contained in other statements, for example, in a letter from 
the Rostov-on-Don group of the ECB, which was received in 1962 by the secretariat of the Presidium of the Supreme Soviet of the USSR: "Moreover, we live at a time when in our country the personality cult, under which we had no right to write with the entreaty that is set forth in this statement, has outlived its usefulness." (Letter from the ECB group of the Baptist Church, 1962, p. 13) The actions of the Initiators were also influenced by political dissidents.

Thirdly, the leaders of the movement were able to provide a spiritual (theological) justification for human rights activities. In short, their position can be expressed as follows: the intervention of an atheistic state in the internal affairs of believers and the "conciliatory" position of the AUCECB ministers had led to a spiritual weakening of the church. Therefore, a revival of the church was impossible without a struggle for its independence from the state, for the right to freely profess its faith, and to educate its children (religious education of one's own children was illegal in Soviet Union).

In "The First Epistle of the Initiative Group to the Church of God" from August 23, 1961, it was stated that "Satan through the AUCECB has brought the church into an emasculated and fragmented state", and that "until the church cleanses itself and takes up a proper state in the eyes of the Lord, the Lord cannot bless us..." (Kryuchkov, 2008 , p. 34). This idea was repeated many times in church documents and sermons throughout the Soviet period. For example, the statement of the Organising Committee (dated October 17, 1963, which was illegally distributed among delegates during the All-Union meeting of the ECB church) read:

It is not a secret that the main difficulties that the Baptist Church is currently experiencing are caused by its ministers' infidelity to God, the infidelity, which has been expressed in the church's illegal and criminal connection to the world. It is no secret that this connection is designed to incorporate the church into the world, leading to its decomposition and ultimate destruction. (Kryuchkov, 2016, p. 424)

Finally, the "human factor" had a special role to play here: the active position, energy and personal authority of the leader of the movement-Gennady Kryuchkov, the long-term Chairman of the CC ECB. From the very beginning, Kryuchkov consistently made the case to his actual and potential supporters concerning the need for civil activity. For example, according to Kryuchkov's recollections, even his closest associate Alexei Prokofiev was embarrassed by the concepts and methods of action unfamiliar to Baptists: "Where do you get all this from: initiative group, organising committee, congress? Where did you learn all this? For me, there is only the Bible, and nothing else is needed." I answer: "It is necessary to know the laws of the country and, in order to defend oneself against lawyer-liars, it is necessary to be no less than these lawyer-liars, it is necessary to know not only the Word of God. [...] We are living in a society, which has got its own laws." (Kryuchkov, 2011, p. 12) Indeed, Kryuchkov was well acquainted with Soviet laws and civil rights, and insisted that other believers find out how to use legal knowledge. 
It seems that if the movement had been headed by another person, the history of the Initiators could have developed differently, most likely following the pattern of so-called illegal Pentecostals: they firmly held onto their faith (for which they were persecuted), but they did not try to defend their rights before the state (with the exception of attempts to leave the USSR).

Thus, human rights activity was not an ultimate goal for the Initiators: it was rather a means to help solve internal church tasks. Most of the participants of the movement were not opponents of the Soviet system as such: apart from religious issues, they were loyal citizens of their country, more appropriately comparable with the communists of the "sixties" than with radical dissidents.

At the same time, one cannot help noticing a certain evolution in the positions of the Initiators: as events unfolded, one part of the believers being tired of persecution and satisfied with certain concessions made by the state, moved to more moderate positions, while the other part continued going in their anti-Soviet sentiments (up to the extent of renouncing Soviet citizenship).

\section{Letters to state and party bodies}

In August 1961, the Initiative Group appealed to the leadership of the AUCECB with a written proposal to convene an extraordinary church congress. Having failed to find support there, on August 23, 1961, the leaders of the movement independently sent an appeal to the head of the government N.S. Khrushchev with a request to allow the congress.

The first documents and actions of the Initiative Group show that the leaders of the youth movement were not categorically inclined, but rather hoped to start a dialogue between the leadership of the AUCEB and state structures. The fact that they themselves offered to hold a church congress contradicted neither state laws, nor Baptist principles (which were rather democratic), or the rules of the AUECB. Unlike the Pentecostals, who founded the Union of Christians of Evangelical Faith at a secret meeting in Kharkov and only then appealed to the authorities to register it, the Initiative Group insisted on holding precisely a lawful congress that was authorised by the government, which testifies to its desire to act strictly within the law, and indicates certain hopes of achieving concrete results in the context of the "thaw".

Soon, at the call of the Initiative Group, in the communities of the ECB, a campaign began to send letters and addresses to the Council for the Affairs of Religious Cults, as well as other state bodies, including party and government leaders. All these letters and appeals contained a request to allow the convocation of a church congress. During the period from August 21 to December 30, 1961 alone, 272 letters (according to other sources, around 400) from Russia, Ukraine, Belarus, Moldova, and Kazakhstan were received by the party and Soviet authorities with requests to permit the congress; the number of signatures in each letter ranged from 1 to 113. In 1962, the flood of letters receded sharply, but resumed in the autumn of 1963, when the Council for the Affairs of Religious Cults received 173 petitions about the congress. For the first time in many years, faced by the mass civil activity of believers, the authorities became alarmed. 
At the end of November 1961, the regional commissioners received the following instruction: "The Council for the Affairs of Religious Cults recommends that you take appropriate measures to prevent the illegal activities of the so-called 'Initiative Group'... on the territory [you are responsible for] ..." (Nikolskaya, 2009, p. 203, 206).

People who had signed letters were warned, threatened and summoned for interviews with the authorities. However, the believers continued to insist their demand be met. It is likely that these events influenced the decision of the authorities, who in 1963 allowed the convening of All-Union Conference-Congress of the ECB church-an assembly that had not taken place since 1944. In 1966, another congress took place (History of ECB of Russia, 2007, pp. 165, 167-168). Both of them were held under the supervision of the AUCECB, which prompted the Initiators to refuse to recognise their outcome and persevere to achieve the convocation of "their own" congress.

Another line of activity taken by the Initiators was the writing of requests for the protection of individual co-religionists (whether arrested or subjected to discrimination) and (in cases of dispersal of assemblies, closing, confiscation of prayer houses, etc.) entire communities.

According to the official data, in the period from 1961 to 1964 alone, 806 people were convicted of religious activities for different periods and more than 400 people were deported for "parasitism" in accordance with the Decree of May 4, 1961 (Nikolskaya, 2009, p. 217). As for Evangelical Baptist Christians, on February 23, 1964 (the date of the founding of the Council of Relatives of Prisoners), there were 141 convicts in the USSR, age ranged between 23 and 76 years (History of Evangelical Christian Baptists of Russia, 2007, p. 167). In 1964, the believers were shocked when the arrested Baptist Nikolay Khmara died in prison as a result of beatings during interrogation (this fact was later recognised at a meeting of the Supreme Court of the USSR on October 12, 1964) (Nikolskaya, 2009, p. 217). Within one and a half month after Khmara's death, the Council of Relatives of Prisoners (CRP) of the ECB was established.

Over time, a system of collecting signatures to support appeals and petitions was established in the communities of the CC ECB. The Council of Relatives of Prisoners carried out thoroughgoing campaigns both in defence of convicted ministers as well as with regard to parents who had been deprived of their children. Often, members of the community, when faced harassment, wrote petitions independently (the latter, however, included not only the Initiators, but also members of the communities of the AUCECB).

For example, the Leningrad community of the CC ECB was meeting in the house of Protsenko in the village of Kuzmolovsky in the Leningrad oblast. Following the decision of the Vsevolozhsk People's Court of April 4,1984, the house was confiscated (the head of the family, Vladimir Protsenko, was at that time in custody), church members sent a petition addressed to the Secretary General of the Communist Party of Soviet Union (CPSU) Central Committee, L. I. Brezhnev and to the USSR Prosecutor General. 81 persons signed the letter (Bulletin CRP, 1984, pp. 52-54).

In an era when a simple signature under the letter was an act of civic courage, many thousands of believers of the ECB participated in the intercessory campaigns. However, there were cases when people later repudiated their signatures or exculpated 
themselves in terms of their incompetence. For example, in December 1967, members of the CC ECB communities in Tula and Novomoskovsk sent a collective letter (190 signatures) to government agencies, in which they described circumstances concerning the bullying of children of believers in schools. However, in the report of the plenipotentiary A. I. Krapivina in 1968, it is detailed that some of the Baptists repudiated their signatures, while others, according to the authorities, gave unconvincing explanations. As a result, the letter was found to be slanderous, although it is more appropriate to assume that some of the signatories subsequently "wavered" in fear for themselves or their children (Bartov, 2017, pp. 130-131).

Although the Initiators did not succeed in all cases, their petitions attracted the attention of the authorities to the problems of the rights of believers, encouraging them to understand these problems, or at least to provide explanations for the authorities' actions.

\section{Delegations to the leaders of the CPSU and the government}

It was not only through written petitions that Baptists Initiators tried to defend their rights. From time to time, entire delegations made their way to Moscow seeking meetings with the party and the government officials. For example, in August 1965, 105 believers of ECB from different parts of the USSR arrived in Moscow to ask for a meeting with Anastas Mikoyan, then Chairman of the Presidium of the Supreme Soviet of the USSR. a few days later, he agreed to accept the five representatives of the delegation, which took place in September 1965 (albeit without achieving any significant results) (Kryuchkov, 2008, p. 239).

The climax of the Initiators' public acts was their massive delegation on May 16-17, 1966. In April 1966, at a meeting in Kiev, the ministers of CC ECB decided to appeal to the government of the USSR with a petition in defence of the rights of believers; for that, a delegation of representatives of communities from different regions of the country was to be sent to Moscow. Those wishing to join the action were to come to Moscow in the morning on May 16, 1966, and, at a prearranged time, to approach the entrance of the Central Committee of the CPSU on Staraya Square (Kujawski, 2014, p. 332). The petition contained certain requests: to allow the convocation of a church congress, to stop the persecution and interference of the state in the affairs of the church, to recognise the CC ECB and to permit the exercise of the right to religious education of the children (Zavatski, 1995, p. 281).

However, KGB units had evidently already got wind of the upcoming action. Some of the believers, when trying to take a leave at their jobs for these days, were refused. Many others, being already on their way to Moscow, were removed from trains by the militia or detained at airports (Kujawski, 2014, p. 333). Nevertheless, on the appointed day, according to various sources, 400-600 Evangelical Christian Baptists from different cities and regions of the USSR came to Moscow (Nikolskaya, 2009, p. 232, 234): for example, from the Kiev community-13 people (Bogdanova, 2014, p. 53); from Leningrad and Pskov-5 (Kuyavsky, 2014, p. 333); from the Gorky region -7 (Yudintseva, 2014, pp. 12-13), and so on. In referring to the figure of 430 
people, the Initiators themselves cite the opinion of the employees of the General Prosecutor's Office that if everyone were to get to Moscow, the number of delegates would reach more than 1500 people (Kryuchkov, 2008, p. 238).

Evgeniy Kujavsky, a minister of the CC ECB community in Leningrad wrote:

On the eve, Brother Mikhail Khorev came to Leningrad to visit us. All our fellow servants and zealots of the work of God gathered together. Brother Mikhail said that it is necessary to go to such a thing voluntarily, since it is not known how this can all end. Five people agreed to go: Vasily Baluev, Alexander Dementyevich Zavyalov, Sister Lida Semenova, a deacon-elder from Pskov and me. (Kujawski, 2014, p. 333)

Upon arriving in Moscow, participants of the delegation then met in the llyinsky Park near Staraya Square, where the building of the Central Committee of the CPSU was located. Here they dispersed at random: some walking around the square, others sitting on benches, etc. Exactly 10 minutes before the start of the action, all participants simultaneously moved to the entrance of the Central Committee to get there exactly at 9 o'clock (according to Kujawski, 10:00). For 2-3 minutes a crowd almost 100 metres long and with a density of 4-5 people was formed at the entrance. When the attendant came out of the door, one of the members of the clergy loudly read out the statement, which was then handed over for transmission to the Politburo of the CPSU Central Committee. After some time, the military security officer proposed that the participants go to a small side street near Staraya Square, where the reception and information department of the Central Committee was located (Kujawski, 2014, pp. 333-334).

The believers followed to this small side street, where they spent the whole day waiting and fasting, and every two hours they pray together on their knees. Following attempts to persuade them to disperse, the authorities then tried to chase them away with the help of a water sprinkler (Kujawski, 2014, p. 334). According to the memoirs of the delegation Galina Yudintseva, the believers spent the night right there in the alley: "They spread out newspapers on the asphalt and those who could sleep, slept right there." (Yudintseva, 2014, p. 13)

The next day, many participants of the delegation fasted again; again, every two hours, they held a prayer. Their anticipation was prolonged. According to the memoirs of E. N. Kujawski,

... The authorities could expect that if they kill the clock, some of us would start leaving the place, and that only a small group would stay for negotiations; that group would then be subjected to beatings (as it had already occurred twice) and then either forcibly sent home or put to the trial. However, not only our number did not reduced; on the contrary, a forty more people joined us. (Kujawski, 2014, pp. 334-335)

When, despite entreaties and warnings, the delegates moved to the entrance of the Central Committee of the CPSU at Nikitsky Pereulok, some buses drove up 
to the location of the action. Militia officers then seized the participants and herded them onto the buses. A. I. Zudin, one of the militia officer, was later testifying at the court against G. K. Kryuchkov and G. P. Vince:

They prayed on their knees as well as standing up. It was rather unpleasant to watch such a huge mass of people kneeling down. They spent the whole night at the building of the Central Committee of the CPSU. The following day their number increased up to about 500 people. [...] Semichastny [the Chairman of the KGB] told them that if they do not leave, he would be forced to put things in order. The buses were provided. [...] We put them into the buses by force, as they were singing. (Nikolskaya, 2009, p. 234)

According to Vasily Ryzhuk, a minister, the delegates were taken by bus first to a racecourse, and then, in the evening, to the Lefortovo prison for filtration (Ryzhuk, 2012, pp. 49-50). Some of the detainees were sentenced to 10-15 days in prison; many others were given fines to pay and other administrative penalties (Kryuchkov, 2008 , p. 239). For example, with the exception of Vera Shuportyak, who became the subject of criminal proceedings, the Kiev delegates were escorted by militia officers back to their homeland after 15 days accompanied by the police (Bogdanova, 2014, p. 53). On May 19, 1966, S. C. George Vince and Mikhail Khorev (CC ECB ministers) came to learn about the fate of detained delegates; they both were arrested in the reception room of the Central Committee of the CPSU. On May 30, 1966, Gennady Kryuchkov, the Chairman of the CC, was arrested in a Moscow apartment (Bratskiy Listok, 1966, No. 6).

Not all participants of the delegation were ready for such an outcome. For example, G. Yudintseva recalled: "My friend [...] was in a cell with a sister from Sumgait. This sister lamented: 'There is no oil here, and they will not provide sausages ...' Apparently, going to Moscow, she did not anticipate the worst." (Yudintseva, 2014, p. 13)

During the summer alone, about 10 trials of ECB were held in Moscow (Bratskiy Listok, 1966, No. 8). The arrests continued over the following months. In September 1966, Church Union members N. G. Baturin and P. A. Yakimenkov, who had been in the delegation, were sentenced to 3 years of imprisonment (Bratskiy Listok, 1966, No. 10). November 29-30, 1966, Moscow trial of G. K. Kryuchkov and G. P. Vince, who, among other things, were accused of "organising a demonstration" (both received 3 years of imprisonment) (Nikolskaya, 2009, pp. 234-235). M. I. Khorev was sentenced to 2.5 years (Khorev Family, 2012).

The delegation of ECB (CU) on May 16-17, 1966 became the largest civil protest action of the "stagnation" era. Information about this event immediately became of international significance. Within both the USSR and elsewhere, the Initiators began to be talked about in terms of a numerous, well-organised, purposeful and selfless religious "opposition movement". Later, some of the young participants of this action joined the ranks of clandestine ministers: for example, the evangelist Joseph Bondarenko (later one of the leaders of the movement of the autonomous churches of the EBC), the workers of the underground publishing house "Christianin" Svetlana Beletskaya, 
Galina Yudintseva, and others. Young people in the CC communities were brought up to admire the example of the boldness and self-sacrifice of delegates. At the same time, the mass arrests represented a serious blow to the movement. Such large-scale actions on the part of Initiators were not to be repeated.

\section{Appeal to international public opinion}

In terms of a distinct form of human rights activity, special mention should go to the appeal to international public opinion. Soviet Baptists took an ambivalent attitude towards the states of the capitalist world. On the one hand, despite their propensity for isolationism, they were people of Soviet upbringing and consciousness who did not want to go against their homeland-especially under the conditions of a "cold war" that could easily become a "hot" one. The memory of the suffering and numerous victims of the Great Patriotic War (1941-1945) was still fresh in their minds. These simple Soviet people sought peace and were genuinely perplexed when the initiatives of the Soviet government met the mistrust or hostility of other countries. Anti-Soviet propaganda, which was conducted from abroad with the help of radio and imported literature, was also perceived by many people as untrustworthy.

On the other hand, it was no secret to the Soviet people that the standard of living and the degree of freedom in the Western countries was much higher than in the USSR. Protestants knew this, perhaps, better than others did. During the 1960s 1980s foreign guests often appeared in the prayer houses of significant Protestant communities in the large cities - whether famous people like the American pianist Van Cliburn, a Baptist, or various unknown tourists. Fashionably dressed, self-assured and contented with their lives, they showed better than any propaganda that the life of a Christian needs not consist solely of tears and suffering.

The contradictory attitude of believers to their state was expressed by Herman Gortfeld, a Baptist from the city of Frunze (in Kirghiz SSR), who wrote in a letter to L. I. Brezhnev with a request of emigration (dated December 21, 1973): "I do not have any bitterness about the domestic policy of our state, there is no bitterness towards the authorities, but I'm tired of shuddering every time I see a militiaman or a KGB officer." (Bulletin CRP, 1973, p. 28)

In the late Soviet period, many believers sought understanding, sympathy and help outside the Soviet world. More often, it was expressed in apolitical forms communication with foreign co-religionists, receiving religious literature from abroad, etc. However, some believers also began to look elsewhere for sources of legal protection. For example, following his arrest in Moscow, Andrei Amalrik (a dissident writer) saw in the militia station "an old woman dressed in black - a sectarian from Tambov, detained near the embassy of Sierra Leone, which she wanted to enter to pass on letters about the persecution of believers... the Sierra Leoneans would certainly have been surprised to see her if she had managed to get there." (Amalric, 1991, p. 378)

The Initiators were certainly not so naive. They established regular contacts with foreign coreligionists and Christian missions (for example, the "Slavic Mission" in Sweden), through which information of a human rights was agilely transmitted 
abroad. Those convicted of religious activities aroused widespread sympathy in the West on the one hand, as innocent victims of the Soviet regime, on the other, as willing or reluctant opponents of this regime. Many foreigners who visited the USSR or worked there tried to find out about the fate of these prisoners. For example, on the April 6, 1980 in Leningrad, the US Consul General Buchanan and his wife came to the registered Evangelical Christian-Baptist church for the morning Easter service. In a short conversation with the church ministers, he enquired about "the recent arrest in Leningrad of some prominent Baptist preacher, whose name he did not mention. The Consul General tried to find out from the interlocutors whether this was indeed the case and who exactly was arrested." (Zharinov, 1980) It seems the American diplomat was referring to M. V. Khorev, a CC ECB minister, who was in hiding and had actually been arrested in Leningrad on January 27,1980 , shortly before the events described (Khorev Family, 2012).

Following the creation of the Council of Relatives of Prisoners, information on the persecution of ECB believers in the USSR was regularly transmitted abroad. Particularly resonant was the story of the death under suspicious circumstances of Ivan Moiseyev (a member of the unregistered community of the European Baptist Church), a soldier who was serving in the Soviet Army. According to the official version, the young man drowned while swimming in the Black Sea near Kerch. However, his relatives and coreligionists residing in Volintiri in the Moldavian Socialist Soviet Republic claimed that when the zinc-lined coffin was opened, abrasions and burns were found on the head and body of the deceased. Already on August 1, 1972, two weeks following the death of the young man, UN Secretary General Kurt Waldheim sent a statement on behalf of the Moiseyev family to the Soviet Defense Minister Andrei Grechko, the Secretary General of the CPSU Central Committee Leonid Brezhnev and other authorities: "... by the conviction of faith in God, our son and brother Moiseyev Ivan Vasilievich died of terrible martyrly torture ..." The Moiseyev's demanded the appointment of a medical expert commission to find out the circumstances of Ivan's death, as well as for the "criminals who tortured him to be found and brought to justice." (Bulletin of the CRP, 1972, pp. 6-9)

The limits of this article do not allow going into this ambiguous story in detail; however, it is significant that the believers directly addressed not only the leaders of their own state, but also the UN. However, although the story of Moiseyev received a broad international response, in the end this did not help to shed any light on the circumstances of his death.

To what extent were the efforts of believers to communicate internationally effective? In fact, the development of international contacts combined with the signing of a number of international human rights treaties forced the Soviet government to pay more attention to public opinion in other countries.

Georgy Vince, giving an interview following his arrival in the US, said "whenever there was any campaign seeking to offer us support in the West, our treatment by the prison guards and administration changed for the better. In the absence of such support, the conditions of detention immediately deteriorated." (Zavatski, 1995, p. 487) Baptist prisoners also received moral encouragement from knowing that they had 
not been abandoned, that thousands of people in the world were praying for them, participating in campaigns for their release and providing all possible assistance to their families.

There are known cases when Evangelical Christian-Baptist prisoners received early release: for example, A. M. Vatulko, A. P. Pilipenko and E. N. Barin, released early in the beginning of 1978 (Bulletin CRP, 1978, p. 19); though it is not clear whether the influence of domestic and foreign human rights defenders was the cause here, or whether there might have been other reasons for mitigating the fate of prisoners (for example, their good behaviour). But, of course, the international prominence of George Vince, the Secretary of CC ECB, was a contributing factor in his eventual fate. In April 1979, instead of five years after exile, he was deprived of Soviet citizenship by a decision of the Presidium of the Supreme Soviet of the USSR and expelled from the USSR. Vince's family were also given permission to leave along with him. According to the memoirs of his daughter Natalia, the deportation occurred as part of the exchange of five Soviet dissidents for two Soviet spies detained in the United States (Vince, 2000, pp. 164-165, 169). According to his recollections, the minister himself interpreted this decision as "blatant lawlessness" and only left his native country reluctantly (Vince, 1994, p. 250).

Soviet political dissidents (in particular A. D. Sakharov) were also involved in the defence of Baptist Initiators. For example, on November 13, 1970, after a hunger strike had been declared by N.B. Vladykin, the presbyter of an unregistered community of ECB in Tula, a telegram was received by L. N. Dagayev, the Chairman of the Tula City Executive Committee:

Concerned about the hunger strike of the Baptist Vladykin held in protest against the actions of local authorities to confiscate his house allegedly in connection with the religious meetings held there. I hope that the violations of Vladykin's rights may be redressed. His life is in danger. Sakharov, Academician, threetimes Hero of Socialist Labour. (Nikolskaya, 2009, p. 281)

Information about the Initiators regularly appeared in the samizdat journal "Chronicle of Current Events." Initially, it was handed over by Boris Zdorovets, but later, some of the Initiators established contacts with political dissidents, for example, Peter Vince (Zavatski, 1995, p. 486).

At the same time, under the conditions of the Cold War, the theme of freedom of conscience in the USSR perforce assumed a political character, and, in order to compromise the Soviet regime, sometimes unverified rumours, exaggeration or falsification were employed. For example, the Protestant pastor, the leader of the organisation "Jesus Christ to Help the Communist World," Richard Wurmbrandt became the hero of the scandal, publishing a photograph of Dutch or German kids dressed in striped dressing gowns after a swimming pool, claiming they were young Soviet prisoners for faith (Zavatski, 1995, p. 484). Soviet propaganda eagerly seized on this story, disclosed by foreign journalists, with the goal of discrediting not only Wurmbrandt, but also all foreign defenders of Soviet Christians (For example, see: 
Vistunov, Tyutryumov, 1980, p. 93). Such cases genuinely increased the distrust of many Soviet believers towards foreign organisations and the media.

\section{Participation of women in human rights activities}

Women were also extensively involved in the CC activity of promoting human rights. They collected and placed signatures under petitions, prayed for prisoners, helped their families financially and emotionally... The wives and mothers of convicted ministers had a particular role to play in this respect. According to Soviet legislation, only close relatives had the right to find out the fate of the arrested person, to represent his/her interests and to solicit for mitigation. Within the Initiator movement, women also had to be concerned about arrested husbands, sons, etc. Yet in 1964, a new structure appeared, an unusual one for Russian Protestants: The Council of Relatives of Prisoners (CRP).

The date of the formation of the CRP is considered to be February 23, 1964, when Lydia Govorun, Nina Yastrebova and Lyubov Rudneva met to organise petitions for persecuted co-religionists (Kryuchkov, 2008, p. 454). The CRP set the following tasks: to collect all available information about persecution, to transfer this information to international institutions, to create petitions to the authorities to stop persecutions, and to organise assistance to the families of the prisoners (Belyakova \& Dobson, 2015, pp. 351-352).

At first, the Council of Relatives of Prisoners was led by Lydia Govorun from Smolensk, who in 1963 was deprived of parental rights with respect to her 9-year-old son Seryozha. The mother had no choice but to assert her rights regarding her child. After the believers went public with this story, the verdict of the court was declared to have been "in error". According to Deputy Prosecutor B. Kravtsov, Govorun was guilty solely of leading the boy to worship and "as a mother, she is innocent of wrongdoing" (Nikolskaya, 2009, p. 197). In 1966, L. K. Govorun was arrested and sentenced to 3 years' imprisonment (Kryuchkov, 2008, p. 459). Then, for a long time, the CRP was led by Lydia Vince, the mother of the twice-convicted George Vince, the Secretary of the CC. When, in 1970, she was also sentenced to 3 years, the CRP was briefly led by Galina Rytikova (Zavatsky, 1995, p. 283). After the departure of Lydia Vince to the US, together with her exiled son, she was replaced by Alexander Kozorezov ("Affirm, o God, what You did for us!", 1989, p. 9).

Since 1970, in addition to regular lists of prisoners distributed among the believers, the illegal "Bulletin of the ECB Council of Relatives of Prisoners" was regularly published. This samizdat publication presented information about all cases of persecution known to the CRP (arrests, searches, dispersals of prayer meetings, harassment of children, etc.), as well as the texts of petitions and any responses to them (typically negative).

It remains a mystery how these women, mostly burdened by families, managed to travel so actively around the country, to study a lot of complicated cases, to write and send letters of intercession, and above of all these, to prepare the forthcoming issue of the "Bulletin" under the conditions of its legal proscription. Not all believers approved of this activity, considering the primary task of a married woman to be the 
upbringing of their own children, and not the public activity. In addition to L. Govorun and L. Vince, eight other participants in the ministry's service were sentenced to various terms of imprisonment (Kryuchkov, 2008, p. 463).

Nevertheless, the CRP continued to operate right up to the time of Perestroika. For believers, it became a kind of authority, to which one could turn for help. According to the memoirs of Nikolay Boyko, the CC minister, in 1968, following his arrest, the authorities attempted to take away the children from his family. Then his wife Valentina "went to the Council of Relatives of Prisoners and sent a telegram to Brezhnev about all the lawlessness committed against the small children, also reporting this to the whole church. After the petitions, the persecution of the children stopped." (Boyko, 2007, pp. 65-66)

Bot only family women, i.e. the wives or mothers of convicted ministers, engaged in human rights activities. For example, one of active human rights defenders was Aida Skripnikova, a believer from the Leningrad Community of the CC ECB. Born in 1941 to a Christian family, she came to Leningrad from the Urals as a young girl, and subsequently went to work for a building trust (Serdobolskaya \& Vistunov, 1976, p. 118). In 1961, Skripnikova joined the movement of Baptist Initiators in Leningrad, participating in the writing and dissemination of religious and human rights materials; she was summoned to the public court with a group of other girls for the distribution of evangelistic leaflets (Nikolskaya, 2009, pp. 207208). Her poems and polemical articles, actively disseminated via samizdat, were also transmitted abroad. In 1968, Aida Skripnikova was arrested and sentenced to 3 years' imprisonment for the systematic distribution of materials from the CC ECB, containing "knowingly false fabrications defaming the Soviet state and social system" (Belyakova \& Dobson, 2015, p. 186). Despite remaining an ordinary member of the church, Skripnikova acquired almost higher prominence abroad than male ministers. She became the subject of many books, articles and radio programmes, with thousands of believers around the world praying for her and standing up in her defence. In this case, the personal disinterestedness of A. M. Skripnikova in terms of copyright to her work is illustrated by the fact that N. Belyakov and M. Dobson, the authors of the work "Women in the Evangelical Communities of Post-war USSR" published her works with the permission of Radio "Svoboda" / Radio "Svobodnaja Europa" (which were storing the materials in samizdat form) and not that of the writer herself or her relatives.

Evidently, Aida Skripnikova not only possessed courage and sincere faith, she also was a very gifted author, although she had no opportunities-and, probably, no desire-to develop her talent purposefully. In the USSR, there was a system of literary associations (lito) for novice authors, through which virtually all future writers had passed. However, the desire for a professional and creative career was not welcomed in the Protestant milieu during the Soviet era. In addition, if a Baptist girl had brought her verses about God to lito, she would at best have received advice to "change the subject"; at worst, exposed to ridicule, mockery, or even being reported to KGB. We can say that Skripnikova nevertheless realised her literary gift (including in the area of human rights activities). 
As it was mentioned above, the Council of Relatives of Prisoners operated up until the time of Perestroika. In September 1987, it was reorganised into the Department of Intercession of the CC ECB (Kryuchkov, 2008, p. 463). The Department continues to operate up to this day, making public some cases of violations of the rights of coreligionists, mainly in the countries of the former USSR.

\section{Attitude of ECB to human rights activities}

Paradoxically, while the Initiators' protection of the rights of believers brought them international fame and even succeeded in encouraging the omnipotence Soviet power to make some concessions, this very human rights activity turned out to be most vulnerable to criticism from within their own Baptist community. Their appeal to the authorities, especially to foreign entities, met the most persistent criticism and rejection. Kryuchkov wrote in his memoirs: "They say that if there were no activities of the Initiators Group, there would be no persecutions" (Kryuchkov, 2011 , p. 8)-an opinion, he probably heard on many occasions. Y. F. Kuksenko, a prominent minister, who later withdrew from the movement, believed that the May 1966 delegation was not only useless, but actually intensified the arrests; its numerical strength did not contribute to the organisation of negotiations, but rather appeared as an annoying challenge and "demonstration of power" to the authorities (Kuksenko, 2005, pp. 133-134).

In addition to a natural fear that this would only complicate their situation, believers sustained a persistent unwillingness to engage in politics. Even the members of the CC communities were embarrassed to turn for help to the authorities and not to God. In their materials, the Initiators underlined their avoidance of using "political" concepts like "demonstration", "protest", "human rights", etc.

Human rights activities were even more negatively perceived by loyal Baptists. For example, Sergey Fadyukhin, the AUCECB minister, recalled that in 1966, in an interview with George Vince, he among the errors of the Council of Churches he listed the following: "In your messages and leaflets you criticise not only the actions of the AUCECB, but also the actions of the government and authorities. [...] And the greatest mistake, which is very difficult to make up for, is that you asked for help abroad." According to Fadyukhin, Vince replied that "we did not want and do not want to receive approval or reprimand from abroad. [...] But there are unreasonable people among us ..." (Almanac on the History of Russian Baptism, 2004, pp. 257-258).

The actions of the authorities against the Initiators sometimes affected loyal Baptists. For example, in 1976, following the appearance of an article about G. P. Vince in "The Literary Gazette", the authorities of the Novgorod region decided to "deal with" the unregistered community of the ECB in the settlement of Parfino, which was incidentally on the side of AUCECB. R. V. Nikolaeva, a community member complained in a letter to L. I. Brezhnev: "Representatives from the region began to come to us; I was summoned to the headquarters two times. These visitors from the region came to our workplaces and gave talks; we were held 
up in front of all our colleagues as people who represented a threat to society..." (Nikolskaya, 2009, p. 271).

Finally, Soviet propagandists skilfully used the genuine or imaginary international links of the Initiators in order to compromise them. According to the memoirs of Nikolay Boyko, the CC minister, in 1968, following his arrest in Voznesensk (Mykolayiv oblast, Ukraine), rumours of his alleged anti-Soviet ties with the United States were circulating in the city. During the trial, local residents tried to get into the hall to look at the "material evidence": "concerning the weapon, the store of which was allegedly found in my house; the radio, via which I supposedly communicated with America". Learning that this evidence did not exist, the residents were outraged by the deception, with some even expressing sympathy for Boyko (Boyko, 2007, p. 69-70). But many Soviet people considered not only "subversive" activities, but also any appeal to foreign entities to be criminal.

\section{Conclusion}

It can be concluded that the human rights activities of Baptist Initiators had mixed consequences. On the one hand, their speeches and petitions with references to Soviet laws combined with international publicity objectively influenced the adjustment of Soviet religious policy. In the second half of the 1960s, the process of registering ECB communities intensified; the authorities even introduced a system of autonomous registration for communities who were ready to comply with legislation on cults, but did not want to join the AUECB. In a number of cases, Baptists managed to get children returned to their parents, to mitigate the fate of convicted ministers, and so on.

However, the human rights activities of the Initiators led not only to concessions by the authorities, but also to persecution, new arrests and trials. The persecution of Baptist Initiators in various forms continued up until Perestroika. Only then did the position of believers in the USSR change dramatically. The last CC ECB prisoners were released in late 1988 (Consoled by Common Faith, 1990, p. 23).

The contemporary successor of the Council of the Churches is the International Union of Churches (IUC) ECB, which was given this name in 2001 at the congress in Tula ("The Lord ... visited His people and created deliverance to him", 2001, p. 5). Nowadays the Initiators pay special attention to the study of their history, constantly publishing new documentary materials, memoirs and research. For this purpose, a special Historical and Analytical Department was established at the IUC ECB. According to the official concept, the positive changes in the country were brought about by the human rights activities of the Initiators ("intercession ministry"), combined with their faithfulness to God:

The open speech of the Initiative Group's ministers in defence of the violated rights of believers broke the 30-year silence of the church. Their fearless call to action marked a new milestone in the history of the brotherhood - the revival of the intercession of the whole church! [...] Like a fertile stream, the numerous petitions of the Initiative Group, the Organising Committee, churches, groups 
and individual believers of the brotherhood, stirred and revived the once-silent camp [...] Everything that the brotherhood requested in petitions with prayer and fasting according to the will of God-was realised ... (Intercession-the Spiritual Heritage of the Awakened Church, 2009)

However, now, the International Church Union of the ECB is perhaps the "quietest" Protestant denomination in Russia, standing away from any public activity. Meanwhile, Protestants of other denominations perceive the human rights experience of the Initiators rather as heroism (or delusion) of the recent past, and not as a practical example to be followed.

\section{References}

Al'manakh po istorii russkogo baptizma (2004). [Al'manakh on the History of Russian Baptism]. St. Petersburg: The Bible for All.

Amalrik, A. (1991). Zapiski dissidenta [Notes of a Dissident]. Moscow: Joint Venture "Slovo".

Bartov, V. P. (2017). Evangel'skie khristiane-baptisty v Tul'skoi oblasti: povsednevnaia zhizn' veruiushchie [Evangelical Christian Baptists in the Tula region: everyday Life of believers (1945-1991)]. Manuscript (in preparation for publication).

Belyakova, N. A., \& Dobson, M. (2015). Zhenshchiny $v$ evangel'skikh obshchinakh poslevoennogo SSSR. 1940-1980-e gg. Issledovanie $i$ istochniki [Women in evangelical communities of the post-war USSR. 1940s-1980s. Research and sources]. Moscow: Indrik.

Biulleten' SRU (1972). [Bulletin of the CRP]. 9, 6-9.

Biulleten' SRU (1973). [Bulletin of the CRP]. 13, 27-28.

Biulleten' SRU (1978). [Bulletin of the CRP]. 51, 19.

Biulleten' SRU (1984). [Bulletin of the CRP]. 121, 52-55.

Bogdanova, L. (2014). Radostnoe poprishche [The joyous field]. Publisher is not indicated.

Boyko, N. E. (2007). Veriu $v$ bessmertie [I believe in life eternal]. Publishing House "The Christian" MSC ECB.

Bratskii listok (1966). [Brotherly Pamphlet]. 6.

"Gospod'... posetil narod Svoi i sotvoril izbavlenie emu" (2001). ["The Lord ... visited his people and created deliverance to him"]. Herald of Truth, 4, 2-5.

Goneniia na Svidetelei legovy v Rossii. Spetsial'nyi otchet (2017). [Persecution of Jehovah's Witnesses in Russia. Special report. Retrived from: https://www.jwrussia.org/sites/default/files/global_additional/17-06-19_special_report_rus.pdf 
Khorev, M. (2012). Stranitsy zhizni [Pages of life]. Herald of Truth, 4, 3-43.

Kryuchkov, G. (2008). Velikoe probuzhdenie XX veka [The Great Awakening of the $20^{\text {th }}$ century]. Publishing House "The Christian" MSC ECB.

Kryuchkov, G. K. (2011). Pobeda ot Gospoda! [Victory from the Lord!]. Publisher is not indicated.

Kryuchkov, G. K. (2016). Ot smerti v zhizn' [From death to life]. Publisher is not indicated.

Kuksenko, Y. F. (2005). Nashi besedy [Our conversations]. Publishing House “Title", Germany.

Kujawski, E. (2014). Ostat'sia vernym [Remain faithful]. Saint Peterburg. Publisher is not indicated.

Nikolskaya, T. K. (2009). Russkii protestantizm i gosudarstvennaia vlast' v 19051991 godakh [Russian protestantism and state Power 1905-1991]. St. Petersburg: Publishing House of the European University.

Pamiatnaia zapiska Orgkomiteta (1962) [Memorandum of the Organising Committee]. State Archives of the Russian Federation (GARF). F.-6991, op. 4, d. 133, I. 4-5.

Pis'mo gruppy EKhB g. Rostova-na-Donu (1962). [Letter from the Rostov-onDon ECB group]. State Archives of the Russian Federation (GARF). F.R.-4173, op. 5, d. 140, I. 13.

Ryzhuk, V. F. (2012). Ispytanie very [Test of faith]. Publishing House "The Christian" MSC ECB.

Sem'ia Khorevykh. Stranitsy zhizni M. I. Khoreva. 1931-2012 (2012). [Family of the Khorev's. Pages in the Life of M. I. Khorev. 1931-2012]. Slide show.

Serdobolskaya, L., \& Vistunov, E. (1976). Pod prikrytiem Evangeliia [Under the Cover of the Gospel]. Leningrad: Lenizdat.

Uteshilis' obshchei veroi (1990). [Consoled by common faith]. Herald of Truth, 3, 23-26.

"Utverdi, Bozhe, to, chto Ty sodelal dlia nas!" (1989). ["Assert, O God, that which You have done for us!"]. Herald of Truth, 4, 2-11.

Vince, G. P. (1994). Evangelie $v$ uzakh [The Gospel in bonds]. Kiev: IPP "Compass".

Vince, N. (2000). The Frontiers of Childhood. Publisher is not indicated.

Vistunov, E., \& Tyutryumov, M. (1980). Litsa bez masok [Faces without masks]. Leningrad: Lenizdat. 
Yudintseva, G. I. (2014). Samye schastlivye dni [The happiest days]. Publisher is not indicated.

Zastupnichestvo-dukhovnoe nasledie probuzhdennoi tserkvi (2009). [Intercession-The Spiritual Heritage of the Awakened Church]. Booklet.

Zavatsky, V. (1995). Evangelicheskoe dvizhenie v SSSR posle vtoroi mirovoi voiny [The Evangelical Movement in the USSR after the Second World War]. Moscow: Garant.

Zharinov, G. (1980). Dokladnaia zapiska v SDR o prazdnovanii Paskhi $v$ Leningrade [Report in the SDR on the Celebration of Easter in Leningrad]. State Archives of the Russian Federation (GARF), F.R.-6991, op. 6, d. 1851, I. 33. 